\title{
Food selection by calanoid copepods in the euphotic layer of the Gotland Sea (Baltic Proper) during mass occurrence of $\mathbf{N}_{2}$-fixing cyanobacteria
}

\author{
Bettina Meyer-Harms***, Marcus Reckermann***, Maren Voß, Heike Siegmund****, \\ Bodo von Bodungen
}

Baltic Sea Research Institute, Dept of Biological Oceanography, Seestrasse 15, 18119 Rostock-Warnemünde, Germany

\begin{abstract}
Food selection by 2 dominant calanoid copepods, Acartia sp and Temora longicornis, was studied during mass occurrence of $\mathrm{N}_{2}$-fixing cyanobacteria in June/July 1993 and 1994 in the Gotland Sea (Baltic Proper). The aim of this study was to assess the importance of $\mathrm{N}_{2}$-fixing cyanobacteria in the diet of calanoid copepods. Two different methods were used: firstly the analysis of marker carotenoids by HPLC (high-performance liquid chromatography), and secondly the analysis of $\delta^{15} \mathrm{~N}$ signals of copepods by mass spectrometry. The first method provides a 'snapshot' of autotrophic material ingested; the second method summarises a longer period, and gives evidence that a certain food source is not only ingested but also assimilated. In 1994, mass occurrence of cyanobacteria showed a higher concentration in the euphotic layer than $1993\left(97 \mu \mathrm{g} \mathrm{Cl}^{-1}\right.$ in $1994,57 \mathrm{\mu g} \mathrm{C} \mathrm{l}^{-1}$ in 1993), which was reflected in higher food uptake of $\mathrm{N}_{2}$-fixing cyanobacteria in 1994 . The average relative amount of myxoxanthophyll, the specific carotenoid of $\mathrm{N}_{2}$-fixing cyanobacteria, in the copepod guts showed high values in 1994 (Acartia sp. 37\%, T. longicornis 41\%) and low values in 1993 (1\% for both copepods). The low $\delta^{15} \mathrm{~N}$ values of both Acartia sp. and T. longicornis in 1994 (9\%) compared to those in 1993 $(10.5 \%)$ support the results of HPLC analyses, because $\mathrm{N}_{2}$-fixing cyanobacteria have a lower $\delta^{15} \mathrm{~N}$ (average $0.7 \%$ ) than eukaryotic phytoplankton (average $12 \%$ ). The low $\delta^{15} \mathrm{~N}$ values in 1994 indicate that $\mathrm{N}_{2}$-fixing cyanobacteria were not only ingested but also assimilated by the copepods to a higher extent in 1994 than 1993.
\end{abstract}

KEY WORDS: Selective feeding $\cdot \mathrm{N}_{2}$-fixing cyanobacteria $\cdot$ Acartia $\mathrm{sp}$. Temora longicornis $\cdot$ Baltic Sea

\section{INTRODUCTION}

So far little attention has been paid to the importance of $\mathrm{N}_{2}$-fixing cyanobacteria as a food resource for zooplankton in the Baltic, despite their mass accurrence each summer. Most studies of the trophic relationship between copepods and cyanobacteria have focused on freshwater environments (e.g. Lampert 1981, Holm \&

·E-mail: bmeyer-harms@awi-bremerhaven.de

Present addresses:

-Alfred Wegener Institute for Polar and Marine Research. Handelshafen 12, 27570 Bremerhaven, Germany

-.'Research and Technology Centre West Coast of Kiel University, Hafentörn, 25761 Büsum, Germany

....Department of Geology and Geochemistry, Stockholm University, 10691 Stockholm, Sweden
Sharpio 1984, Fulton \& Pearl 1987a,b, 1988, DeMott 1989, Ahlgren et al. 1990). These studies are based mainly on laboratory experiments and show that cyanobacteria are generally not preferred by copepods because of the bad manageability of the filaments, nutritional inadequacy or toxicity (e.g. Lampert 1987 , Ahlgren et al. 1990). On the other hand field experiments in lakes demonstrate that copepods are capable of ingesting filamentous and colonial forms of cyanobacteria (DeMott \& Moxter 1991, Schaffner et al. 1994).

In the marine environment only a few studies have examined the nutritional value of cyanobacteria for calanoid copepods and these have yielded contradictory results. Schmidt \& Jónasdóttir (1997) reported that cyanobacteria in small quantities cannot necessarily be considered as poor food. Guo \& Tester (1994) found 
that Acartia tonsa only ingest healthy intact cells of Trichodesmium sp. when no other food is available. Heerkloss et al. (1984) estimated assimilation efficiencies of 50 to $80 \%$ for $A$. tonsa when they fed on the cyanobacteria Microcystis areuginosa, while an assimilation efficiency of $35 \%$ was found when they fed on the cyanobacteria Oscillatoria redeckii. Field studies have shown low grazing on filamentous cyanobacteria by copepods and cladocerans during bloom conditions in temperate estuarine or brackish waters (Sellner et al. 1993, 1994, 1996). This result contrasts with that found for zooplankton feeding on cyanobacteria in freshwater environments (see above).

Therefore we conducted a more detailed survey on feeding behaviour of Acartia sp. and Temora longicornis in the Baltic Proper during mass occurrence of $\mathrm{N}_{2}$ fixing cyanobacteria. We used 2 complementary methods: marker carotenoid analyses by high-performance liquid chromatography (HPLC) in copepod guts to estimate actual food uptake (Kleppel \& Pieper 1984, Kleppel et al. 1988, Swadling \& Marcus 1994), and $\delta^{15} \mathrm{~N}$ analyses of copepods by mass spectrometry that summarise feeding strategy of copepods over a longer period, giving evidence that a certain food source is not only ingested but also assimilated (Montoya 1994). The question we wanted to answer is: How important are $\mathrm{N}_{2}$-fixing cyanobacteria as a food source for calanoid copepods during their bloom in the Baltic Proper?

\section{MATERIALS AND METHODS}

Description of the study area and sampling procedure. In the Baltic Sea during summer months blooms of $\mathrm{N}_{2}$-fixing, filamentous cyanobacteria are a regular

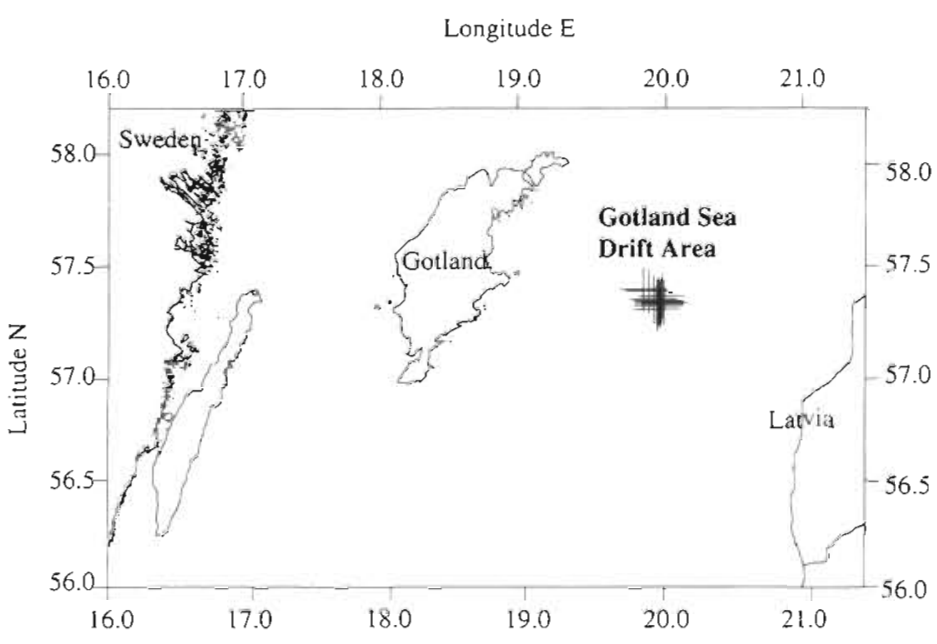

Fig. 1. Drift area in the Gotland Sea (Baltic Proper) studied in the periods June 28 to July 2, 1993, and July 18 to July 22, 1994 phenomenon (Kahru et al. 1994), thought to be caused by a shift from phosphorus to nitrogen limitation (Granéli et al. 1990). The major bloom forming species are Aphanizomenon flos-aquae, Nodularia spumigena and Anabaena sp. (Hübel \& Hübel 1995). In addition the non- $\mathrm{N}_{2}$-fixing picocyanobacteria Synechococcus $\mathrm{sp}$. occur in high cell numbers $\left(10^{6}\right.$ cells $\left.\mathrm{ml}^{-1}\right)$ in the Baltic Proper (Jochem 1990). These are, however, due to their small size ( 1 to $2 \mu \mathrm{m}$ ), considered unsuitable as food for copepods (Johnson et al. 1982).

Samples were taken from a water body marked with a drifting buoy (for details see Voß et al. 1997) during cruises of the RVs 'Professor Albrecht Penck' (June 28 to July 2, 1993) and 'Alexander v. Humboldt' (July 18 to July 22,1994$)$ east of Gotland $\left(57^{\circ} 17^{\prime} \mathrm{N}, 20^{\circ} \mathrm{E}\right)$ in the central Baltic Sea (Fig. 1). Sampling was done every day during a 5 d drifting period.

Sampling of copepods. Copepods were collected after sunset at the same stations as the water samples using a $200 \mu \mathrm{m}$ mesh ring net (0.75 m diameter), towed vertically between 0 and $25 \mathrm{~m}$ depth. Immediately after capture, samples were screened onto a $200 \mu \mathrm{m}$ gauze and frozen in liquid nitrogen for further species separation in the laboratory. For pigment analyses, adult Acartia sp. and Temora longicornis, the dominant copepods in the euphotic layer, were isolated under a binocular microscope equipped with a cold table under dim light and washed 3 times in cold water $\left(0^{\circ} \mathrm{C}\right)$, to remove attached algae. Between 500 and 700 individuals of each species were collected on glass-fibre filters (Whatman $\mathrm{GF} / \mathrm{F}$ ) for pigment analyses and stored at $-80^{\circ} \mathrm{C}$ for further analyses by HPLC.

Phytoplankton sampling. Water was collected from discrete depths (1 $\mathrm{m}$ only for pigment analyses, 5, 10 , 15,20 and $25 \mathrm{~m}$ ) in both years using a rosette water sampler equipped with $12 \mathrm{l}$ bottles. Subsamples were taken for estimation of phytoplankton biomass by microscope counts and flow cytometry, HPLC analyses of marker pigments, quantification of suspended particulate material (SPM), and $\delta^{15} \mathrm{~N}$ analyses of SPM and $\mathrm{N}_{2}$-fixing cyanobacteria. The methods used are described in detail below.

Estimation of phytoplankton biomass. Subsamples (0.5 l) were taken for analyses by light microscopy, epifluorescence microscopy (in 1993) and flow cytometry (in 1994).

Light microscopy: A 0.25 l subsample was fixed with $1 \%$ Lugol's solution and analysed under an inverted microscope at $\times 100$ and $\times 400$ magnification after settling (Utermöhl 1958). Algae $>15 \mu \mathrm{m}$ (see Table 1) present as filaments ( $\mathrm{N}_{2}$-fixing cyanobacteria), chains (e.g diatoms) and large unicellular algae (e.g Dinophysis norvegica) were counted by this 
Table 1. Dominant filamentous, chain-forming and unicellular autotrophic species and their size range estimated during the study periods in 1993 and 1994 . 'Counted by light microscopy, " counted by epifluorescence microscopy (in 1993) and flow cytometry (in 1994)

\begin{tabular}{|c|c|}
\hline Autotrophic group & Dominant species \\
\hline \multicolumn{2}{|c|}{ Algae cells present in filaments and chains $(>15 \mu \mathrm{m})$} \\
\hline $\mathrm{N}_{2}$-fixing cyanobacteria & $\begin{array}{l}\text { Anabaena sp." } \\
\text { Aphanizomenon flos-aqua } \\
\text { Nodulania spumigena. }\end{array}$ \\
\hline Diatoms & $\begin{array}{l}\text { Thalassiosira baltica } \\
\text { Skeletonema gracile } \\
\text { Chaetoceros costatum }\end{array}$ \\
\hline \multicolumn{2}{|c|}{ Unicellular species $>15 \mu \mathrm{m}$} \\
\hline Dinoflagellates & Dinophysis norvegica ${ }^{*}$ \\
\hline \multicolumn{2}{|c|}{ Unicellular species $<15 \mu \mathrm{m}$} \\
\hline Dinoflagellates & $\begin{array}{l}\text { Prorocentrum minimum ". } \\
\text { Katodinium rotundatum." } \\
\text { Gymnodinium simplex." }\end{array}$ \\
\hline Cryptophytes & Rhodomonas sp." \\
\hline Prasinophytes & Cf. Pyramimonas spp. $\cdot$ \\
\hline Haptophytes & Cf. Prymnesium parvum ". \\
\hline Cyanobacteria & Synechococcus spp. $\cdot$ \\
\hline
\end{tabular}

technique. The identified and counted algae were converted from biovolume to carbon values as described by Edler (1979).

Epifluorescence microscopy in 1993: For counting of unicellular autotrophic nano- and picoplankton (algae cells $<15 \mu \mathrm{m}$, see Table 1) 2 to $5 \mathrm{ml}$ of the samples were filtered onto black polycarbonate filters (pore size $0.2 \mu \mathrm{m}$ ), which were then transferred to microscope slides and stored at $-20^{\circ} \mathrm{C}$ until they were counted in the laboratory under an ZEISS Axioskop epifluorescence microscope at $\times 400$ magnification. The autotrophic cells were identified by their shape and bright red and orange autofluorescence under green excitation light (ZEISS filter set 48.79.00, excitation filters BP530-585, beam splitter FT600, long-pass emission filter LP615). A minimum of 400 cells were counted per sample and converted to biomass by using cell biovolumes calculated from individual cell size measurements, and applying the carbon conversion factors according to Verity et al. (1992).

Flow cytometry in 1994: A Partec PAS III flow cytometer was used to count unicellular autotrophic nanoand picoplankton $(<15 \mu \mathrm{m}$, see Table 1). The instrument was equipped with a tuneable Argon laser (max. power $300 \mathrm{~mW}$ ), adjusted to $488 \mathrm{~nm}$. Emission light was detected as red (>630 nm, chlorophyll) and orange (560 to $590 \mathrm{~nm}$, phycobilins) fluorescence light. Perpendicular light scatter was detected at the proper laser wavelength of $488 \mathrm{~nm}$. Signals were recorded on a 3-decade logarithmic scale. Absolute sample volume was $700 \mu \mathrm{l}$.
For biomass estimation, an approximate size determination of nano- and picoplankton cells was carried out by size fractionation. Water samples were passed through meshes or polycarbonate filters of different pore sizes ( 2 to $15 \mu \mathrm{m}$ ). The respective filtrates were then measured in the flow cytometer The pore size retaining approximately $50 \%$ of a population (as measured in the cytometer) was taken as the approximate equivalent spherical cell diameter. Biomasses were calculated based on the cell numbers in the unfractionated samples and the approximate equivalent spherical diameters, using the carbon conversion factors according to Verity et al. (1992).

Marker pigment analysis by HPLC. Subsamples for HPLC $(0.5$ to $1 \mathrm{l})$ were filtered through Whatman GF/F filters (25 $\mathrm{mm}$ in diameter) and stored in liquid nitrogen for analysis in the laboratory. The frozen GF/F filters were extracted with $5 \mathrm{ml} 100 \%$ methanol buffered with $2 \%$ ammonium acetate $(3 \mathrm{ml}$ for the copepod samples) and analysed by HPLC using the method described by Kraay et al. (1992). A detailed description of this method and the HPLC system is given by Meyer-Harms \& Pollehne (1998).

Myxoxanthophyll served as a marker for $\mathrm{N}_{2}$-fixing cyanobacteria. This pigment is absent in the non- $\mathrm{N}_{2}$ fixing pico-cyanobacteria Synechococcus sp. (Zeitzschel pers. comm. and author's unpubl. data), which was abundant at our sampling sites during the study periods (Reckermann 1996). In both years, 6 pigments were selected as primary taxonomic markers to represent the major groups in the autotrophic community (Table 2).

Estimation of selective feeding behaviour. Food selection of specific phytoplankton groups was quantified using the selectivity index (SI) after Ivlev (1961): $\mathrm{SI}=(r-p) /(r+p)$, where $r$ is the percentage of its marker pigment in the gut and $p$ is the percentage of its marker pigment in the euphotic layer. SI was calculated as follows: For the terms $r$ and $p$ of the eukaryotic phytoplankton, the sum of the frequency of all marker pigments that represent this group was used for each

Table 2. Diagnostic pigments for the characterisation of the different algal groups (Hirschberg \& Chamovitz 1994, Jeffrey et al. 1997) in the euphotic zone during the study periods in 1993 and 1994 in the Gotland Sea

\begin{tabular}{|ll|}
\hline Autotrophic group & Marker carotenoids \\
\hline$N_{2}$-fixing cyanobacteria & Myxoxanthophyll \\
Diatoms & Fucoxanthin \\
Dinoflagellates & Peridinin \\
Cryptophytes & Alloxanthin \\
Prasinophytes & Prasinoxanthin \\
Haptophytes & $19^{\prime}$-hexanoyloxyfucoxanthin \\
\hline
\end{tabular}


depth. A mean value over the whole depth range was calculated for both groups (eukaryotic phytoplankton, cyanobacteria), because copepod samples were taken from $25 \mathrm{~m}$ depth to the surface. SI varies theoretically between -1 and +1 , with $\mathrm{SI}=0$ indicating non-selective feeding on an algal group, $0 \leq \mathrm{SI} \leq+1$ indicating an increasing preference for a phytoplankton group and $0 \geq \mathrm{SI} \geq-1$ indicating an increasing discrimination against an algal group. SI indices were calculated for each sampling day during the $5 \mathrm{~d}$ drifting period in both years, followed by a calculation of an average of the results from the $5 \mathrm{~d}$ sampling period.

Analysis of nitrogen (N) and $\delta^{15} \mathrm{~N}$. For $\delta^{15} \mathrm{~N}$ analyses of adult Acartia sp. and Temora longicornis, 90 to 120 adult individuals of each species were collected from the frozen $200 \mu \mathrm{m}$ gauze and transferred to a pre-combusted GF/F filter. For the determination of $\mathrm{N}$ and the $\delta^{15} \mathrm{~N}$ of SPM, water samples (0.5 to $1 \mathrm{l}$ ) were filtered onto GF/F filters. For the analysis of $\mathrm{N}$ and $\delta^{15} \mathrm{~N}$ of $\mathrm{N}_{2}$ fixing cyanobacteria, seawater samples were passed through a $100 \mu \mathrm{m}$ gauze and transferred into filtered seawater for further separation. Trichomes were isolated under a binocular microscope and transferred onto a GF/F filter with an inoculation loop.

All filters prepared for $\mathrm{N}$ and $\delta^{15} \mathrm{~N}$ analyses were stored at $-20^{\circ} \mathrm{C}$. Before analysis in a Carlo Erba CE 1108 elemental analyser coupled to a Finnigan MAT Delta $S$ isotope ratio mass spectrometer the filters were dried at $60^{\circ} \mathrm{C}$ for $12 \mathrm{~h}$ and pelletised. For details see Voß et al. (1997). All isotope abundances were measured relative to a working standard of ultra high purity $\mathrm{N}_{2}\left(\delta^{15} \mathrm{~N}=-8.09 \%\right)$ and expressed as per mil $(\%)$ deviation from the isotopic composition of atmospheric $\mathrm{N}_{2}$ using the $\delta^{15} \mathrm{~N}$ convention: $\delta^{15} \mathrm{~N}(\%)=\left[\left(R_{\text {sample }} /\right.\right.$ $\left.\left.R_{\text {standard }}\right)-1\right] \times 1000 ; R=\left({ }^{15} \mathrm{~N} /{ }^{14} \mathrm{~N}\right)$.

Isotopically characterised organic standards (peptone, Merck Chemical) were analysed along with each batch of samples. The reproducibility of the values reported in this study was $\pm 0.1 \%$. Both the reference gas and the organic standards have been intercalibrated with IAEA Standard substances.

The concentration of $\delta^{15} \mathrm{~N}$ of the eukaryotic phytoplankton plus detritus was calculated by considering the respective contribution of the $\mathrm{N}_{2}$-fixing cyanobacteria and the SPM as follows:

$$
\delta^{15} N_{E P D}=\left[\left(\delta^{15} N_{S P M} \times N_{S P_{M}}\right)-\left\{\delta^{15} N_{C B} \times N_{C B}\right)\right] / N_{E P}
$$

where EPD stands for the eukaryotic phytoplankton plus detritus, SPM stands for the suspended particulate material and $\mathrm{N}_{\mathrm{SPM}}$ the $\mathrm{N}$ content of SPM, CB stands for the $\mathrm{N}_{2}$-fixing cyanobacteria and $\mathrm{N}_{\mathrm{CB}}$ the $\mathrm{N}$ content of $\mathrm{CB}$, and $\mathrm{N}_{\mathrm{EP}}$ is the nitrogen content of eukaryotic phytoplankton (EP).

$\mathrm{N}_{\mathrm{EP}}$ in Table 5 was calculated by converting the phytoplankton carbon (C) values estimated in this study and shown in Table 3 by using a C:N ratio of 9.0 . This ratio is based on the investigation of Shaffer (1986) in the Baltic Sea. The other parameters used in the equation for calculating $\delta^{15} \mathrm{~N}_{\mathrm{EPD}}$ are given in Table 5.

\section{RESULTS}

\section{Phytoplankton distribution}

The dominant autotrophic species found in the Gotland Sea during 1993 and 1994 are listed in Table 1. In both years the autotrophic community was similar. The $\mathrm{N}_{2}$-fixing cyanobacteria were dominated by Anabaena sp, Aphanizomenon flos-aquae and Nodularia spumigena. Their biomass decreased with depth in both years (Table 3 ) from $>100 \mu \mathrm{g} \mathrm{C} \mathrm{l}^{-1}$ at $5 \mathrm{~m}$ depth to 1 (1993) and $40 \mu \mathrm{g} \mathrm{Cl}^{-1}$ (1994) at $25 \mathrm{~m}$ depth, while the biomass of eukaryotic phytoplankton in the euphotic layer did not vary much between years (94 to $120 \mu \mathrm{g} \mathrm{C}$ $\left.\mathrm{1}^{-1}\right)$. An exception was observed in 1994, when a high eukaryotic algae biomass of $239 \mu \mathrm{g} \mathrm{Cl}^{-1}$ was found at $15 \mathrm{~m}$ depth, resulting from an accumulation of the large dinoflagellate Dinophysis norvegica. From 5 to $25 \mathrm{~m}$ depth the cyanobacteria biomass was 1.1- to 40-fold higher in 1994 than in 1993 (Table 3).

In 1993, the pigment myxoxanthophyll, the biomarker of $\mathrm{N}_{2}$-fixing cyanobacteria, dominated the pigment composition (Fig. 2) from 1 to $5 \mathrm{~m}$ (mean $62 \%$ ); in 1994 it dominated from 1 to $10 \mathrm{~m}$ (mean $65 \%$ ). The relative amount of marker carotenoids of the different eukaryotic phytoplankton groups increased from 15 to $25 \mathrm{~m}$ depth in 1993 and represented more than $80 \%$ of all pigments detected, while in 1994 the values were $<71 \%$ (Fig. 2). The estimated pigment distributions of the marker carotenoids for $\mathrm{N}_{2}$-fixing cyanobacteria and eukaryotic phytoplankton in the euphotic layer are consistent with the distribution pattern for both groups estimated by cell counting (see Table 3 \& Fig. 2).

Table 3. Biomass of autotrophic organisms ( $\mathrm{N}_{2}$-fixing cyanobacteria and eukaryotic phytoplankton) in the euphotic layer during the study periods in 1993 and 1994 in the Gotland Sea $(\mathrm{n}=5, \pm \mathrm{SD})$

\begin{tabular}{|c|c|c|c|c|}
\hline \multirow[t]{2}{*}{$\begin{array}{l}\text { Depth } \\
\text { (m) }\end{array}$} & \multicolumn{2}{|c|}{$\begin{array}{l}\mathrm{N}_{2} \text {-fixing cyano- } \\
\text { bacteria }\left(\mu \mathrm{g} \mathrm{Cl}^{-1}\right)\end{array}$} & \multicolumn{2}{|c|}{$\begin{array}{l}\text { Eukaryotic phyto- } \\
\text { plankton }\left(\mu g \mathrm{Cl}^{-1}\right)\end{array}$} \\
\hline & 1993 & 1994 & 1993 & 1994 \\
\hline 5 & $120 \pm 52$ & $134 \pm 54$ & $104 \pm 24$ & $95 \pm 55$ \\
\hline 10 & $118 \pm 39$ & $163 \pm 61$ & $109 \pm 15$ & $94 \pm 39$ \\
\hline 15 & $41 \pm 18$ & $118 \pm 28$ & $110 \pm 42$ & $239 \pm 107$ \\
\hline 20 & $7 \pm 2.0$ & $31 \pm 14$ & $99 \pm 8$ & $115 \pm 53$ \\
\hline 25 & $1+0.3$ & $40 \pm 23$ & $120 \pm 17$ & $99 \pm 51$ \\
\hline
\end{tabular}


a
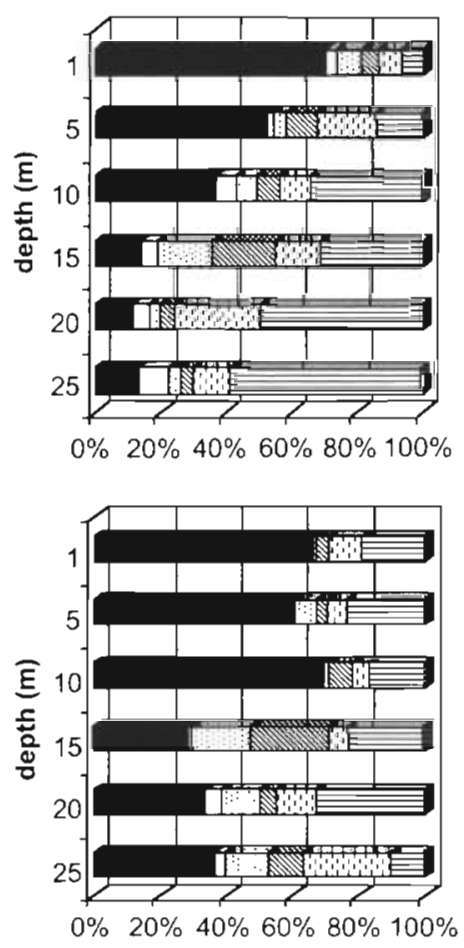

b
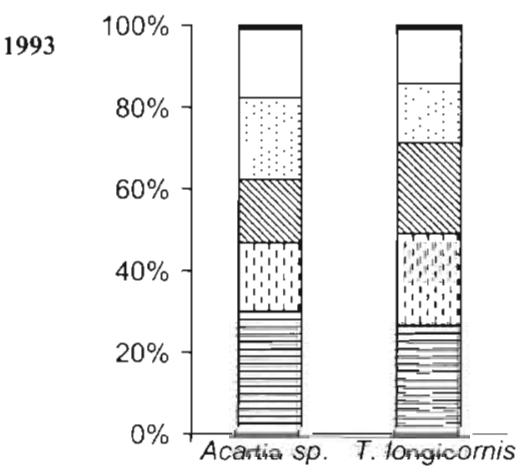

1994

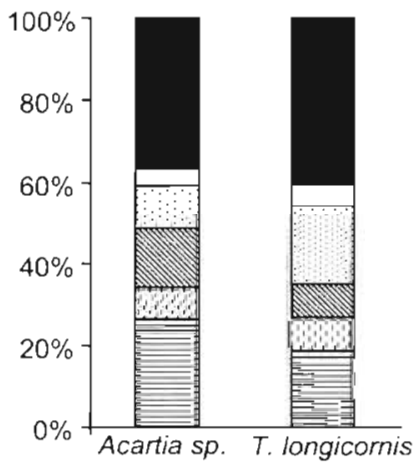

\section{Grazing activity of calanoid copepods}

The higher concentration of cyanobacteria in the water body in 1994 compared to in 1993 was reflected by a higher relative amount of the corresponding pigment myxoxanthophyll in the copepod guts (1993: Acartia sp. $1.1 \%$ and Temora longicornis 1.2\%, 1994: Acartia sp. $37 \%$ and T. longicornis $40 \%$, Fig. 2). In 1993, the calculated selectivity index (SI) showed a selection of eukaryotic phytoplankton by both copepods, whereas in 1994 a more opportunistic feeding behaviour on both cyanobacteria and eukaryotic phytoplankton was observed (Table 4).

The $\delta^{15} \mathrm{~N}$ of the nutritional sources, $\mathrm{N}_{2}$-fixing cyanobacteria $\left(\delta^{15} \mathrm{~N}_{\mathrm{CB}}\right)$ and eukaryotic phytoplankton plus detritus ( $\delta^{15} \mathrm{~N}_{\mathrm{EPD}}$ ) increased with depth in the euphotic layer (Table 5). The $\delta^{15} \mathrm{~N}_{\mathrm{CB}}$ isolated from the field ranged from 0.2 to $1.2 \%$ in 1993 and 0.5 to $1.4 \%$ in 1994 . The calculated $\delta^{15} \mathrm{~N}_{\text {EPD }}$ showed values from 8.0 to $16.5 \%$ (average $11.9 \%$ ) and 5.8 to $18 \%$ (average $11.6 \%$ ) in 1993 and 1994 , respectively. The isotope values of the 2 food sources estimated in the present study are comparable with those found in the literature for each group (Michener \& Schell 1990, Wada $\&$ Hattori 1991). The increase of $\delta^{15} \mathrm{~N}$ of the 2 different nutritional sources with depth found in this study may be explained by the utilisation of heavier nitrogen sources from the underlying water (Voß et al. 1997), which stems from remineralisation and denitrification processes.

The calanoid copepods Acartia sp. and Temora longicornis had average $\delta^{15} \mathrm{~N}$ signals of $11 \%$ in 1993 and 9\% in 1994 (Fig. 3). Regarding the differences in $\delta^{15} \mathrm{~N}$ of the prospective food sources (see above) the $\delta^{15} \mathrm{~N}$ of the copepods should decrease with increasing amount of ingested $\mathrm{N}_{2}$-fixing cyanobacteria. In fact the relative low $\delta^{15} \mathrm{~N}$ values of the copepods in 1994 correspond to a relatively high amount of the marker carotenoid of $\mathrm{N}_{2}$-fixing cyanobacteria (myxoxanthophyll) in the copepod guts. However the high standard deviation of the $\delta^{15} \mathrm{~N}$ values means that the differences are not statistically significant. The reported range of

Table 4. Selectivity indices (SI) of Acartia sp. and Temora longicornis on the autotrophic material in the euphotic zone in 1993 and 1994 ( $\mathrm{n}=5$ ) calculated according to Ivlev (1961). SI = 0: non-selective feeding on an algal group; $0 \leq \mathrm{SI} \leq+1$. increasing preference for a phytoplankton group; and $0 \geq \mathrm{SI} \geq-1$ : increasing discrimination against an algal group

\begin{tabular}{|lcccc}
\hline \multirow{2}{*}{$\begin{array}{l}\text { Nutritional } \\
\text { source }\end{array}$} & \multicolumn{2}{c}{1993} & \multicolumn{2}{c}{1994} \\
\hline $\begin{array}{l}\mathrm{N}_{2} \text {-fixing } \\
\text { cyanobacteria }\end{array}$ & $-0.95 \pm 0.03$ & $-0.95 \pm 0.05$ & $-0.14 \pm 0.05$ & $-0.10 \pm 0.1$ \\
$\begin{array}{l}\text { Eukaryotic } \\
\text { phytoplankton }\end{array}$ & $0.29 \pm 0.11$ & $0.29 \pm 0.17$ & $0.11 \pm 0.05$ & $0.08 \pm 0.06$ \\
\hline
\end{tabular}


Table 5. $\delta^{15} \mathrm{~N}$ and $\mu \mathrm{mol} \mathrm{N}$ of possible food sources for Acartia sp. and Temora longicornis during the investigations in 1993 and 1994 in the Gotland Sea $(n=5, \pm S D)$. SPM: suspended particulate material, CB: isolated $\mathrm{N}_{2}$-fixing cyanobacterid, EPD: eukaryotic phytoplankton plus detritus and EP: eukaryotic phytoplankton. The $\mu$ mol $N_{E p p}$ were calculated by using the mean values shown in Table 3 and a C:N ratio of 9.0 (Shaffer 1986), where $8^{15} \mathrm{~N}_{\mathrm{EPD}}$ values were calculated by using the mean values of the other food sources shown here. For details see 'Materials and methods'

\begin{tabular}{|c|c|c|c|c|c|c|c|c|c|c|c|c|}
\hline \multirow{2}{*}{$\begin{array}{l}\text { Depth } \\
(m)\end{array}$} & \multicolumn{2}{|c|}{$\delta^{15} N_{\text {SPM }}$} & \multicolumn{2}{|c|}{$\mu \mathrm{mol} \mathrm{N}_{\mathrm{SPM}}\left(\mathrm{l}^{-1}\right)$} & \multicolumn{2}{|c|}{$\delta^{15} N_{\mathrm{CB}}$} & \multicolumn{2}{|c|}{$\mu \mathrm{mol} N_{C B}\left(l^{-1}\right)$} & \multicolumn{2}{|c|}{$\delta^{15} N_{\text {EPD: }}$} & \multicolumn{2}{|c|}{$\mu \mathrm{mol} N_{E P}\left(I^{-1}\right)$} \\
\hline & 1993 & 1994 & 1993 & 1994 & 1993 & 1994 & 1993 & 1994 & 1993 & 1994 & 1993 & 1994 \\
\hline 5 & $1.9 \pm 0.1$ & $1.4 \pm 0.2$ & $5.0 \pm 1.4$ & $5.7 \pm 1.4$ & $0.2 \pm 0.01$ & $0.5 \pm 0.02$ & $1.1 \pm 0.06$ & $1.3 \pm 0.04$ & 9.3 & 8.1 & 1.0 & 0.9 \\
\hline 10 & $1.3+0.1$ & $1.8 \pm 0.1$ & $6.4 \pm 1.4$ & $6.4 \pm 1.1$ & $0.2 \pm 0.01$ & $0.5 \pm 0.01$ & $1.5 \pm 0.03$ & $1.8 \pm 0.04$ & 8.0 & 11.8 & 1.0 & 0.9 \\
\hline 15 & $3.4 \pm 0.3$ & $2.8 \pm 0.1$ & $3.6 \pm 0.7$ & $5.0 \pm 0.7$ & $0.2 \pm 0.02$ & $0.9 \pm 0.04$ & $0.5 \pm 0.01$ & $1.3 \pm 0.05$ & 12.1 & 5.8 & 1.0 & 2.2 \\
\hline 20 & $5.4 \pm 0.5$ & $6.1 \pm 0.6$ & $2.4 \pm 0.1$ & $2.9 \pm 0.7$ & $0.7 \pm 0.04$ & $1.4 \pm 0.06$ & $0.8 \pm 0.02$ & $1.3 \pm 0.08$ & 13.8 & 14.4 & 0.9 & 1.1 \\
\hline 25 & $6.8 \pm 0.8$ & $6.0 \pm 0.4$ & $2.9 \pm 0.1$ & $2.9 \pm 0.8$ & $1.2 \pm 0.08$ & $0.8 \pm 0.02$ & $1.3 \pm 0.09$ & $1.5 \pm 0.12$ & 16.5 & 18.0 & 1.1 & 0.9 \\
\hline
\end{tabular}

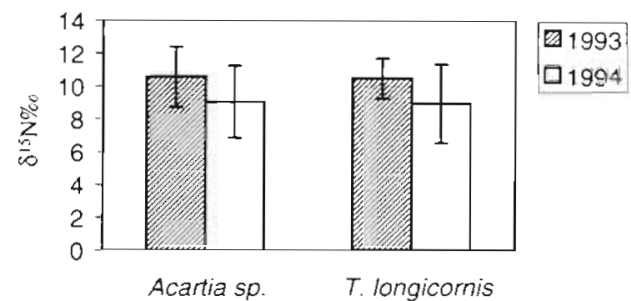

Fig. 3. Mean $\delta^{15} \mathrm{~N}$ values of Acartia sp. and Temora longicornis in the euphotic layer during the study period 1993/1994 in the Gotland Sea $(n=20, \pm S D)$

$\delta^{15} \mathrm{~N}$ of zooplankton measured in the Baltic Sea ( 8 to $14 \%$, Hansson et al. 1997) is consistent with the data presented in our study and can therefore be explained by different feeding strategies.

\section{DISCUSSION}

The present study has shown that cyanobacteria were utilised by calanoid copepods, a finding which is consistent with previous results. Schmidt \& Jónasdóttir (1997) found from laboratory experiments that small additions of a cyanobacterium Microcystis sp. to a diatom diet led to a greater rate of egg production than on a pure diatom diet. This was suggested to result from the biochemical composition of cyanobacteria, which complements the nutrition derived from diatoms. Turner et al. (1998) reported from Kingston Harbour, Jamaica, that during bloom conditions of filamentous cyanobacteria, marine copepods and cladocerans showed a variable and inconsistent ingestion pattern on natural assemblages of phytoplankton and cyanobacteria without presenting any explanation for this phenomenon. The authors observed that copepods and cladocerans not only ingested entire cyanobacterial filaments, but also appear to bite off portions of filaments. Such 'filament clipping' on cyanobacteria has been reported for several freshwater zooplankton organisms (Schaffner et al. 1994 and references therein). Estimation of cyanobacteria uptake by zooplankton based on counting filaments only is therefore questionable.

The 2 methods applied in this study examine the food uptake during different phases of the metabolic process. Marker carotenoid analyses in copepod guts provide 'snapshot' information of autotrophic material ingested, while $\delta^{15} \mathrm{~N}$ signals of the copepods summarise feeding strategy over a longer period and provide evidence that a certain food source is not only ingested but also assimilated (e.g. Montoya 1994).

According to the marker pigment method Acartia sp. and Temora longicornis grazed more on eukaryotic phytoplankton than on $\mathrm{N}_{2}$-fixing cyanobacteria. However, the distribution of myxoxanthophyll, the marker pigment of $\mathrm{N}_{2}$-fixing cyanobacteria, in the copepod guts differed considerably between sampling periods in the Gotland Sea. Higher values were found in 1994 than in 1993. These findings are supported by $\delta^{15} \mathrm{~N}$ measurements. According to the average $\delta^{15} \mathrm{~N}$ values of the autotrophic food sources in the euphotic layer ( $\mathrm{N}_{2}$-fixing cyanobacteria, eukaryotic phytoplankton) an ingestion of both food sources but with a preference for eukaryotic phytoplankton can be assumed. Nevertheless the lower mean $\delta^{15} \mathrm{~N}$ value of the copepods in 1994 compared to 1993 shows that $N_{2}$-fixing cyanobacteria were ingested and assimilated to a greater extent in 1994. This suggestion thus contrasts with that of Pfannkuche \& Lochte (1993) that cyanobacteria are well protected against digestion.

The present study provides the first investigation using nitrogen isotope signatures to analyse copepod grazing on $\mathrm{N}_{2}$-fixing cyanobacteria in the Baltic Proper. $\delta^{15} \mathrm{~N}$ analyses seem a useful tool for differentiating between $\mathrm{N}_{2}$-fixing cyanobacteria and other nutritional sources of calanoid copepods. Isotope fractionation is influenced by assimilation and excretion processes (Montoya 1994), but it is unclear how these processes are related to each other. By answering these open questions, $\delta^{15} \mathrm{~N}$ analyses might be a useful 
tool for quantifying trophic relationships in the aquatic environment and may contribute to a better understanding of the feeding behaviour of zooplankton.

The different feeding behaviour found for Acartia sp. and Temora longicornis on cyanobacteria in 1994 compared to 1993 may be explained by 2 hypotheses: (1) a higher cyanobacteria biomass existed in 1994 than in 1993, especially in the deeper part of the euphotic zone; and (2) there was a later phase of the cyanobacteria bloom in 1994 compared to 1993.

In support of Hypothesis 1 a 50-fold higher amount of myxoxanthophyll was found in the 20 to $25 \mathrm{~m}$ depth layer in 1994 compared to 1993 (see Table 3), which is reflected in a 33-fold higher amount of myxoxanthophyll in the copepod guts in 1994. Therefore, it is possible that the higher amount of myxoxanthophyll in the copepod guts in 1994 was a result of the opportunistic feeding behaviour of both copepods on cyanobacteria caused by the higher cyanobacterial biomass at 20 to $25 \mathrm{~m}$ depth during that year. This explanation is supported by the calculated SI, which indicates that the 2 copepods fed on $\mathrm{N}_{2}$-fixing cyanobacteria in 1994 according to their abundance (see Table 4).

Hypothesis 2 is supported by results of Hoppe (1981) and Repka et al. (1998). Hoppe (1981) reported a fauna of microzooplankton (e.g. ciliates, flagellates, rotifers) to be associated with aged agglomerates of $\mathrm{N}_{2}$-fixing cyanobacteria. Thus cyanobacteria in a late phase of a bloom may be a more tasty and nutritious food for copepods. Repka et al. (1998) found in feeding experiments with Daphnia galeatha that detritus derived from the filamentous $\mathrm{N}_{2}$-fixing cyanobacteria Oscillatoria limnetica was of higher food quality than live filaments and supported growth and reproduction of $D$. galeatha. Therefore differences in the feeding behaviour of the calanoid copepods on cyanobacteria in 1993 and 1994 might be explained by ageing processes of cells during bloom development, which increased their attractiveness as a food source.

This study shows that $\mathrm{N}_{2}$-fixing cyanobacteria in the Baltic Proper are ingested and probably assimilated to some degree by calanoid copepods. Open questions remain on the change of their nutritional values with ageing processes and changes of feeding strategies of copepods related to their nutritional status. These studies are worthwhile, because, as shown here, the role of cyanobacteria as food for calanoid copepods seems to be so far underestimated.

Acknowledgements. We are grateful to the captain and crew of the RVs 'Professor Albrecht Penck' and 'Alexander v. Humboldt' for their collaboration. We thank P. Kähler and especially J. Harms for their helpful discussions and comments on a previous version of the manuscript. Special thanks to A Atkinson for helpful comments and improving the English.

\section{LITERATURE CITED}

Ahlgren G, Lundstedt L, Brett M, Forsberg C (1990) Lipid composition and food quality of some freshwater phytoplankton for cladoceran zooplankters. J Plankton Res 12 : $809-818$

DeMott WR (1989) Optimal foraging theory as a predictor of chemically mediated food selection by suspension-feeding copepods. Limnol Oceanogr 34:140-154

DeMott WR, Moxter F (1991) Foraging on cyanobacteria by copepods: responses to chemical defenses and resource abundance. Ecology 12:1820-1834

Edler L (1979) Recommendations on methods for marine biological studies in the Baltic-Sea-phytoplankton and chlorophyll. The Baltic Mar Publ 5:1-38

Fulton RS, Pearl HW (1987a) Toxic and inhibitory effects of the blue-green alga Microcystis aruginosa in herbivorous zooplankton. J Plankton Res 9:837-855

Fulton RS, Pearl HW (1987b) Effects of coloniality on zooplankton utilization of resources during blue-green algal Microcystis aruginosa blooms. Limnol Oceanogr 32: $634-644$

Fulton RS, Pearl HW (1988) Effects of the blue-green alga Microcystis aruginosa on zooplankton competitive relations. Oecologia 76:383-389

Granéli E, Wallström K, Larsson U, Granéli W, Elmgren R (1990) Nutrient limitation of primary production in the Baltic Sea area. Ambio 19:142-1.51

Guo C. Tester PA (1994) Toxic effect of the bloom-forming Trichodesmium sp. (Cyanophyta) to the copepod Acartia tonsa. Natural Toxins 2:222-227

Hansson S, Hobbie JE, Elmgren R, Larsson U, Fry B, Johansson $S$ (1997) The stable nitrogen ratio as a marker of foodweb interactions and fish migration. Ecology 78:2249-2257

Heerkloss R, Arndt $H$, Hellwig $J$, Vietinghoff $U$, Georgi $F$, Wessel B, Schnese W (1984) Consumption and assimilation by zooplankton related to primary production in the Baltic coastal water inlet Barther Bodden. Limnologica 15: 387-394

Hirschberg J, Chamovitz D (1994) Carotenoids in cyanobacteria. In: Bryant DA (ed) The molecular biology of cyanobacteria. Kluwer Academic Publishers, Dordrecht, p 559-579

Holm NP, Sharpio JS (1984) An examination of lipid reserves and the nutritional status of Daphnia pulex fed Aphanozomenon flo-aquae. Limnol Oceanogr 28:677-687

Hoppe HG (1981) Blue-green algae agglomeration in surface water: a microbiotope of high bacterial activity. Kiel Meeresforsch Sonderh 5:291-303

Hübel H, Hübel M (1995) Blooms of blue-green algae in the Baltic-Sea: causes-dimensions - consequences. Dtsch Hydrogr Z Suppl 2:151-158

lvlev VS (1961) Experimental ecology of the feeding of fishes. Yale University, New Haven

Jeffrey SW, Mantoura RFC, Bjornland T (1997) Data for the identification of 47 key phytoplankton pigments. In: Jeffrey, Mantoura RFC, Wright SW (eds) Phytoplankton pigments in oceanography. UNESCO, Paris, p 449-559

Jochem $F(1990)$ Distribution and importance of autotrophic picoplankton in the western baltic and its potential as a food source. Br Phycol J 25:90-91

Johnson PW, Huai-Shu X, Sieburth JM (1982) The utilization of chroococcoid cyanobacteria by marine protozooplankton but not by calanoid copepods. Ann Inst Oceanogr Paris Nouv Ser 58:297-308

Kahru M. Horstmann U, Rud O (1994) Satellite detection of increased cyanobacteria blooms in the Baltic Sea: natural fluctuations or ecosystem change? Ambio 23:469-472 
Kleppel GS, Pieper RE (1984) Phytoplankton pigments in the gut contents of planktonic copepods from coastal waters off southern California. Mar Biol 78:193-198

Kleppel GS, Pieper RE, Trager G (1988) Variability in the gut contents of individual Acartia tonsa from waters off southern California. Mar Biol 92:185-190

Kraay GW, Zapata $M$, Veldhius MJ (1992) Separation of chlorophylls $c_{1}, c_{2}$ and $c_{3}$ of marine phytoplankton by reversed-phase-C18-high-performance liquid chromatography. J Phycol 28:708-712

Lampert W (1981) Inhibitory and toxic effects of blue-green algae on Daphnia. Int Rev Ges Hydrobiol 66:285-298

Lampert W (1987) Laboratory studies on zooplanktoncyanobacteria interactions. NZ J Mar Freshw Res 21: $483-490$

Meyer-Harms B, Pollehne F (1998) Alloxanthin in Dinophysis norvegica (Dinophysiales, Dinophyceae) from the Baltic Sea. J Phycol 34:280-285

Michener RH, Schell DM (1990) Stable isotope ratios as tracers in marine aquatic food webs. In: Lajtha $\mathrm{K}$, Michner $\mathrm{RH}$ (eds) Stable isotopes in ecology and environmental science. Blackwell Scientific, Oxford, p 138-151

Montoya JP (1994) Nitrogen isotope fractionation in the modern ocean: implications for the sedimentary record. In Zahn R, Pedersen TF, Kaminski MA, Labeyrie L (eds) Carbon cycling in the glacial ocean: constraints on the ocean's role in global change, Vol 17. NATO ASI Series, SpringerVerlag, Berlin, p 259-279

Pfannkuche O, Lochte K (1993) Open ocean pelago-benthic coupling: cyanobacteria as tracers of sedimenting salp faeces. Deep-Sea Res I 40:727-737

Reckermann M (1996) Ultraphytoplankton and protozoan communities and their interactions in different marine pelagic ecosystems (Arabian Sea and Baltic Sea). Mar Sci Rep Baltic Sea Res Inst 14

Repka S, Van der Vlies M, Vijverberg $J$ (1998) Food quality of detritus derived from the filamentious cyanobacterium Oscillatoria limnetica for Daphnia galeata. J Plankton Res 20:2199-2205

Schaffner WR, Hairston NG Jr, Howarth RW (1994) Feeding

Editorial responsibility: Otto Kinne (Editor),

Oldendorf/Luhe, Germany rates and filament clipping by crustacean zooplankton consuming cyanobacteria. Verh Int Ver Limnol 25: $2375-2381$

Schmidt K, Jónasdóttir SH (1997) Nutritional quality of two different cyanobacteria: How rich is 'poor' food? Mar Ecol Prog Ser 151:1-10

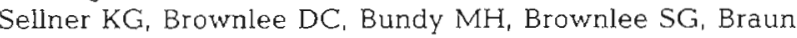
KR (1993) Zooplankton grazing in a Potomac River cyanobacteria bloom. Estuaries 16:91-97

Sellner KG, Olson MM, Kononen K (1994) Copepod grazing in a summer cyanobacteria bloom in the Gulf of Finland. Hydrobiologia 292/293:249-254

Sellner KG, Olson MM, Olii K (1996) Copepod interactions with toxic and non-toxic cyanobacteria from the gulf of Finland. Phycologia 35(Suppl 6):177-182

Shaffer G (1986) Redfield ratios, primary production, and organic carbon burial in the Baltic Sea. Deep-Sea Res 34: $769-784$

Swadling KM, Marcus NM (1994) Selectivity in the natural diets of Acartia tonsa Dana (Copepoda: Calanoida): comparison of juveniles and adults. J Exp Mar Biol Ecol 181. $91-103$

Turner JT, Russel R, Hopcroft J, Lincoln A, Huestis CA, Tester PA, Rof JC (1998) Zooplankton feeding ecology: grazing by marine copepods and cladocerans upon phytoplankton and cyanobacteria from Kingston Harbour, Jamaica, PSZN I: Mar Ecol 19:195-208

Utermöhl H (1958) Zur Vervollkommnung der qualitativen Phytoplankton-Methodik. Mitt Int Theor Angew Limnol 9: $1-38$

Verity PG, Robertson CY, Tronzo CR, Andrews MG, Nelson JR, Sieracki ME (1992) Relationships between cell volume and the carbon and nitrogen content of marine photosynthetic nanoplankton. Limnol Oceanogr 37:1434-1446

Voß M, Nausch G, Montoya JP (1997) Nitrogen stable isotope dynamics in the central Baltic Sea: influence of deepwater renewal on the N-cycle changes. Mar Ecol Prog Ser 158:11-21

Wada E, Hattori A (1991) Nitrogen in the sea: forms, abundances and rate processes. CRC Press, Boca Raton

Submitted: September 11, 1998; Accepted: July 13, 1999 Proofs received from author(s): December 9, 1999 